\title{
The acceptance and use of online shopping in Limpopo province
}

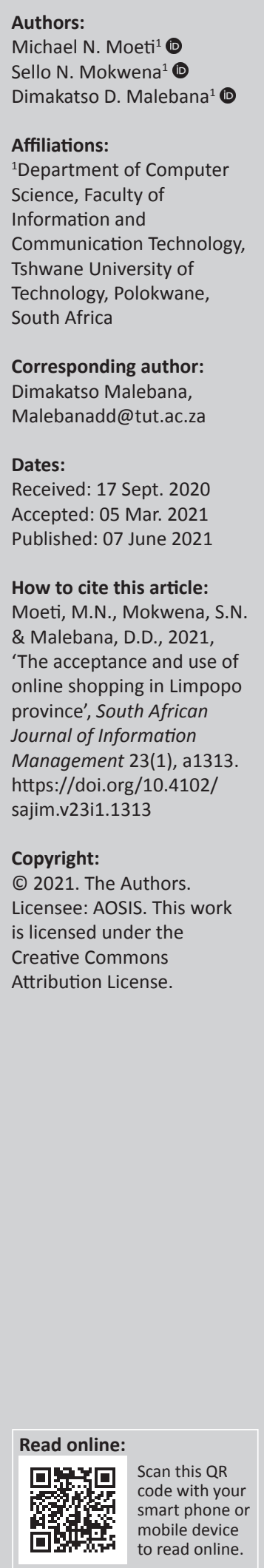

\section{Authors:}

Affiliations:

Department of Computer

Tshwane University of

Technology, Polokwane,

Dimakatso Malebana

Dates:

Accepted: 05 Mar. 2021

\& Malebana, D.D., 2021,

The acceptance and use of

province',

Journal of Information

Management 23(1), a1313.

https://doi.org/10.4102/

Copyright:

(C) 2021. The Authors.

is licensed under the

Creative Commons

\begin{abstract}
Background: The retail industry globally provides online shopping services to offer consumers easy access to a variety of shopping services. Like retailers in other countries, the retail industry in South Africa offers online shopping services to its consumers. South African consumers in Limpopo province are still reliant on the traditional shopping method, despite the convenience, ease of access and the elimination of physical boundaries offered by online shopping.
\end{abstract}

Objectives: This article investigated and discussed the factors which affect the acceptance and use of online shopping by consumers in Limpopo province.

Method: A quantitative research approach was used in this research. Data were gathered using a paper-based questionnaire and were analysed using Statistical Package for Social Sciences (SPSS) software.

Results: The perceived trialability was found to have significant influence on the acceptance and use of online shopping, whereas relative advantage, compatibility, complexity and external variables such as security and awareness were found not to be significant factors in the acceptance and use of online shopping in Limpopo province.

Conclusion: The research revealed that the effectiveness of trialability increased the intention to accept and use online shopping. Retail consumers in Limpopo province did not accept and use online shopping because of the lack of experience and trust. Trialability will make it easy for retail consumers in Limpopo province to build confidence in online s hopping, thus consumers may in the future be willing to accept and use online shopping. Retail consumers were found to be willing to accept and use online shopping.

Keywords: consumers intention; online shopping; online stores; mobile shopping; e-business.

\section{Introduction}

The advent of the Internet era and the use of Electronic Commerce (e-Commerce) together brought about the rise of electronic business (e-Business) worldwide. E-business refers to trading over the Internet. E-business provides convenient service that is user-friendly, transparent and efficient for clients. Consumers are able to use online shopping sites to make price comparisons, product selection and other services offered by different retail stores in the comfort of their homes or offices in comparison to traditional shopping. Janeska et al. (2017) emphasised that online shopping includes a number of possibilities, such as information search, website browsing or navigation, ordering, payment, customer-service interactions, delivery and post-purchase problem resolutions. Advantages of online shopping, as perceived by consumers, include convenience, price, original services (services available online and not anywhere else), personal attention, easy and abundant information access and privacy (Al-Hujran et al. 2018). Although online shopping has many benefits, these have been narrowed to suit specific groups, such as the young, the wealthy, the better educated and the more computer-literate individuals, who often spend their time on the Internet and find online shopping interesting and easy to achieve (Chouk \& Mani 2019). Consequently, consumers outside the groups above are still reluctant to use online shopping.

The current, traditional practice of shopping is often tedious, carrying many limitations and associated risks.

Most consumers often stand in long queues when shopping in a brick and mortar store. This wastes time, especially during month-end and festive seasons. Consumers have to be physically present at a particular shop or retail outlet to do their shopping, and must observe the stores' trading hours, and parking space, inter alia. Online shopping technology can solve many of the problems associated with traditional in-store shopping. Online shopping is a form of E-commerce whereby 
consumers buy goods or services directly from a seller over the Internet (Laxmi \& Sarath 2016). Shafiee and Bazargan (2018) stated that online shopping or e-shopping is a form of electronic commerce that allows consumers to buy goods or services directly from a seller over the Internet, using a web browser. The technology allows marketers and retailers to take advantage of the opportunities presented by the Internet. Online shopping provides consumers with benefits such as lower prices, customisation and faster deliveries, including the convenience of shopping at the time and place of consumers (Katta \& Patro 2017). Maggioni et al. (2020) emphasised that in the online shopping environment, consumers are free to shop at various websites, and they are able to switch from one website to another with just a click. E-commerce adoption is well researched in the context of developed countries; however, there is a dearth of empirical studies that focus on the adoption and acceptance of e-commerce in developing countries (Tarhini et al. 2019). The pace and rate of online shopping are slow in developing countries, especially African countries as indicated by Egbetokun et al. (2017).

Retail consumers in Limpopo province are still using the traditional shopping methods and not accepting and using online shopping despite the availability of online shopping with concomitant benefits and advantages.

The aim of the study was to investigate and explore the factors that may influence the acceptance and use of online shopping in Limpopo province. To conceptualise the theoretical and practical framework for the problem stated above, the following question guided the research: Why are Limpopo Province consumers not using online shopping platforms, regardless of the accessibility of online shopping technology, and the attempt of retail vendors to raise the awareness of online shopping?

\section{Background}

Majority of consumers in Limpopo Province are still using the traditional shopping method despite the availability of online technology that offers convenient shopping. Despite their increasing busy lifestyle and demanding jobs, consumers still regard traditional shopping as an integral part of their life. The aim of this study was to investigate the factors that may influence the acceptance and use of online shopping in Limpopo Province. The following question guided the research and was used to conceptualise the theoretical and practical framework for the problem stated above: Why are Limpopo province consumers not using online shopping platforms, despite the availability of online shopping infrastructure and the effort of retail vendors in promoting online shopping awareness?

\section{Literature review}

Online shopping is a process of buying products using the computer, and portable devices (smartphones) via the Internet. According to Tankovic and Benazic (2018), online shopping is also known as e-shopping, Internet shopping, online-store purchasing and virtual-store purchasing. Rahman (2016) defined online shopping as the process a customer uses to purchase a service or product over the Internet. Jayasubramanian, Sivasakthi and Ananthi (2015) further defined online shopping as the process whereby consumers buy goods and services directly from a seller interactively in real-time, over the Internet without a middle-man. Online shopping is a procedure that contains a number of platforms, which includes the search for product information, the processing and incorporation of information in order to assess alternative product options, as well as the act of purchasing (Sudha \& Sheena 2017). Consumers may at their leisure buy from the comfort of their own home, products from an online store (Sheth 2020). Malhotra and Aggarwal (2019) argued that online shopping requires the existence of retailers' websites through which shopping may be achieved in a virtual environment devoid of physical contact between sellers and buyers.

\section{Impact of online shopping on consumers}

Rodrigues, Oliveira and Costa (2016) stated that online shopping is currently experiencing a rapid growth, owing to its distinctive benefits for both consumers and retailers, such as shopping round the clock facilities, decreased dependence on store outings, saving of travel costs, decreased overhead expenditure and choice of a wide variety of products. Shopping online has become the norm for consumers globally, in that it has many advantages. Fernández-Ferrín et al. (2018) emphasised that consumers can shop at any time and have access to products and services not available in their geographic regions, thus the use of online shopping can help consumers with access to quality products and services available in other geographic regions. The perception of consumers regarding online shopping differs from individual to individual and is limited to a certain extent to the availability of proper Internet connection, and the promotion of online shopping (Duffett 2017; Shanthi \& Kannaiah 2015).

\section{The benefits and challenges of online shopping}

The benefits of online shopping include convenience, time saving, flexibility and consumers being able to shop anytime and anywhere without visiting the retail premises. Online shopping enables consumers to shop and pay online for the products of their choice, having them delivered or collecting them in the store, thus improving consumer's well-being by decreasing the necessity for purchasers to carry money when shopping.

Advantages of online shopping, as identified by consumers, include accessibility, collection, price, original services (services offered electronically and not anywhere else), personal attention, simple and profuse data access and confidentiality (Janeska et al. 2017). Online shopping brings many advantages to consumers, who may shop from 
anywhere having Internet, not needing physically to visit the shops or outlets for shopping purposes (Vaidya \& Vaidya 2017). Compared with brick-and-mortar stores, online stores have many advantages: they are convenient and time-saving, eliminating travelling and waiting time in lines (Rahman et al. 2018).

Although online shopping has many benefits, it has been narrowed to suit specific groups, such as the young, the wealthy, the better educated and the more computer-literate individuals, who often spend their time on the Internet, finding online shopping interesting and fun (Ansell 2016). According to Sheth (2020), from a buyer's point of view, e-commerce offers many tangible advantages, for example, better buyer decisions, less time spent in resolving invoice and order discrepancies and finally, increased opportunities for buying alternative products.

\section{Online shopping in South Africa}

According to the Effective Measure (2017) report, online shopping is increasingly becoming the norm for online audiences in South Africa. Findings reveal that $80 \%$ of online shoppers have either maintained or increased their online shopping habit, with $46 \%$ of offline shoppers reportedly believing that they will make an online purchase within the coming year (Measure 2017). Pillay (2016) stated that South Africans, in general, are growing increasingly confident about shopping online. Large enterprises in South Africa, like their counterparts in developed and similar developing countries, have, to a large degree, accepted e-business (Abdullah et al. 2018). According to Beneke et al. (2016), South African consumers rely on personal information sources before making purchase decisions online. Little was known about market-related Internet activities. Also, little was known about the influence of the market-related activities on the consumers' intention to purchase products over the Internet (Contini et al. 2020).

South Africa had a correlated rise in the use of mobile phones and computer applications for business purposes (DeenSwarray 2016). According to Statistics South Africa (2016b), only $3.5 \%$ of households in South Africa (SA) did not have access to either landline or cellphone in 2016. To date, both the urban and rural areas in South Africa enjoy Internet facilities at various degrees (Bama \& Ragaprabha 2016). South Africa experienced significant growth in e-commerce, although not to the same degree as in the United States of America (USA) and Europe (Elbeltagi et al. 2016).

\section{Online shopping in Limpopo province}

The rapid growth of the Internet has revolutionised the way business is being carried out in the world, and many businesses use it for several strategic goals. Retailers, like Pick n Pay, Checkers, Woolworths and Edgars, are amongst the retailers who have adopted online shopping in order to offer convenient shopping services to their consumers. Retailers, such as Pick n Pay and Woolworths' online shopping platforms, allow or enable consumers to buy products and have them delivered to their homes. Edgars and Checkers enable consumers to buy online and collect the product in store.

The lack of access to technological infrastructure is a key impediment to business growth and adds significantly to the cost of doing business. Thus, lack of Internet resources in Limpopo province results in the community being starved of access to possible services offered by this medium. Today, both urban and rural areas do not enjoy Internet facilities to the same degree with rural areas bearing the brunt (Kavitha 2015). Limpopo is a rural province.

\section{Online shopping security}

Security in online shopping is a significant concern for most consumers, anxious to safeguard their personal information. According to Krishnan et al. (2017), e-commerce security includes three major components, namely, data security, network security and privacy security of the consumer. The online shopping environment, unlike its organisational counterparts, is an extremely fertile field for consumer anxiety, owing to its inherent risks and dangers (e.g. privacy infringement and credit-card fraud) (Celik 2016). Security in e-commerce transactions is an extremely worrying matter for both organisations and individuals. Both parties must safeguard their interests from unauthorised access (Al-maghrabi et al. 2011; Krishnan et al. 2017). Retailers can educate their consumers on their sites by explaining to them their security measures, and assuring compensation if their personal information is compromised. Businesses can make use of social media to improve their reputation by letting customers share their stories with friends, confirming that online shopping is secure. If consumers lack confidence in the security of the online transaction, perceiving it as a risk, this would be the main obstacle to the development of e-commerce (Ansari \& Alhazemi 2016; Dong-Her et al. 2004).

\section{Demographic features of online shoppers}

Demographic features have an impact on consumers' requirements, and the capability of buying goods online.

Several studies have confirmed that age and gender differences are important factors that affect online shopping (Lin et al. 2019).

There is a need to facilitate the creation of wireless information infrastructures, and alleviate the digital divide resulting from differences in family income, educational attainment, occupation, employment status, race, gender, age and geography (Wang et al. 2016). Ling, Jusoh and Ishak (2018) concluded that demographic variables such as income, education and age have a modest impact on the decision whether to buy online, whereas the most important determinant of online shopping was previous behaviour, such as earlier online purchases. 


\section{Theoretical foundation}

The study was based on the Diffusion of Innovation Theory (Rogers 1983), which attempts to identify patterns and rates of how a particular innovation is accepted or rejected by consumers.

The diffusion of innovation theory has five innovation characteristics that influence individuals on the acceptance and use of a particular innovation, namely, relative advantage (the view of advantage in online shopping), compatibility (the enjoyment found in online shopping), complexity (the effort made in online shopping), trialability (experience of the product in online shopping) and observability (the publicity of online shopping) (Rogers 1983):

- Relative advantage is the extent to which an innovation is recognised to be better than its predecessor, often measured in economic terms, social prestige, convenience and satisfaction (Rogers 1983).

- Complexity is defined as the degree to which an innovation is perceived as relatively difficult to understand and use (Rogers 1983).

- Compatibility is defined as the extent to which an innovation meets the potential adopters' present beliefs, adopters' past knowledge and current requirements (Rogers 1983). Compatibility of online shopping is assumed as an important driver of the acceptance and use of online shopping. According to Ramavhona and Mokwena (2016), it is measured in terms of how innovation fits into individual life situations.

- Rogers (1983) defined trialability as the degree to which an innovation may be experimented with on a limited basis. Rogers (1983) further stated that trialability enables potential consumers to develop a specific kind of confidence in online shopping, being willing to accept and use it.

- Two external factors, Awareness and Security, have been added to this study as they are regarded as critical factors in the diffusion of innovations such as online shopping.

- Security of online shopping is associated with the risk of identity theft and fraud consumers. As payment modes in online shopping are most likely made with credit cards, consumers pay attention to the retailers' information in order to protect themselves (Amati 2020).

Researchers, such as Ramavhona and Mokwena (2016), applied the Diffusion of Innovation Theory in the study of Internet Banking in rural areas of South Africa. The Diffusion of Innovation (DOI) may also be used to study the adoption of online shopping (Van Droogenbroeck \& Van Hove 2017). Four key constructs of DOI, relative advantage, compatibility, complexity and trialability, together with two external factors, awareness and security were critical in this study in an attempt to identify the factors that influence the acceptance and use of online shopping in Limpopo province.

\section{Research method and design Hypothesis of this research}

Six hypotheses have been derived from the research questions and the objectives of this study. The research study conducted by Ramavhona and Mokwena (2016) on factors affecting Internet adoption in South African rural areas has revealed that trialability of online banking has a major impact on the adoption of Internet banking. This is supported by other previous studies which indicated that when consumers are given an opportunity of trying a new technology, this would reduce the feelings of fear about the usage of this technology (Bulmer, Elms \& Moore 2018). Hence, the study hypothesises that:

H1: Trialability of online shopping positively affects the intention to accept and use online shopping in Limpopo province.

Based on the diffusion of innovation theory, consumers accept and use online shopping if they perceive relative advantage over traditional shopping methods, such as lower cost or saving in time and effort which make online shopping more convenient (Akroush \& Al-Debei 2015; Choudhury \& Karahanna 2008).

With all this relative advantage of online shopping, it would be expected that online shopping consumers in Limpopo Province would be likely to accept and use the service. The study therefore hypothesises that:

H2: Relative advantage of online shopping positively has an impact on consumer intention to accept and use online shopping in Limpopo province.

Research conducted previously revealed that an innovation having difficulty requires extra effort and better execution in terms of practical and operative skills to support its chances of adoption in the communities (Lau \& Price 2017). Online shopping involves browsing and clicking a user-friendly interface, which leads consumers to believe that online shopping facilities are simple to use, thus enabling them to accept and use the service. According to Rogers (1983), the acceptance will be less likely if an innovation such as online shopping is considered complex to use, and not user-friendly. The study therefore hypothesises that:

H3: Complexity of online shopping will have positive impact on consumers' intention to accept and use online shopping in Limpopo province.

Rogers (1983) described compatibility as the extent to which an innovation meets the potential adopters' present beliefs, adopters' past knowledge and current requirements. A study conducted by Shi et al. (2020) revealed that compatibility is an essential component, affecting the acceptance of online shopping. Consumers who spend most of their time in their daily lives and job on the Internet and using other related technologies are more at ease with online shopping (Zendehdel \& Paim 2015). According to Zendehdel and Paim (2015), the rate of an adoption may either be accelerated or retarded by the compatibility of an innovation with a preceding idea. The study therefore hypothesises that:

H4: Compatibility of online shopping will have a positive impact on consumers' intention to accept and use online shopping in Limpopo province. 
Security of online shopping is associatedwith the risk of identity theft and fraud consumers. As payment modes in online shopping are most likely made with credit cards, consumers pay attention to the retailers' information in order to protect themselves (Haddad, Aïmeur \& Hage 2018). Consumers fear that their personal information and transaction security will be compromised. According to Rabaan et al. (2017), in an online shopping environment, security is defined as the ability of the online company website to protect consumers' information and their financial transaction data from being stolen during transmission. The study, therefore, hypothesises that:

H5: Security of online shopping will have a positive impact on consumers' intention to accept the use of online shopping in Limpopo province.

Rogers (1995) recognised awareness as one of the important attributes of adoption. The adoption or rejection of a particular innovation begins when the intended consumers become aware of the innovation (Rogers 1995). Yaseen, Dingley and Adams (2016) announced that consumer awareness is one of the factors that has a major impact on e-commerce adoption. It is hypothesised that consumers are not sufficiently aware of the concept of online shopping and of the benefits it can provide (Ansari \& Alhazemi 2016). The study, therefore, hypothesises that:

H6: Awareness of online shopping will have a positive impact on consumers' intention to accept and use online shopping.

\section{Research methodology}

The research aimed to investigate and explore the factors that affect the acceptance and use of online shopping in Limpopo province. The researcher adopted a cross-sectional approach during data collection. A sample size of 150 participants was targeted. The data collection for this study was restricted to retail consumers in Limpopo province. A non-probability sampling method was used. This sampling method relies on the personal judgement of the researcher rather than chance to select sample elements (Malhotra \& Dash 2016). A closedended self-administered questionnaire was used as the main method to collect data from the participants in Limpopo province.

The five-point Likert-scale was adopted in designing the questions for this study. All items measured on a five-point Likert-scale, using Strongly Agree (SA), Agree (A), Uncertain (U), Disagree (D) and Strongly Disagree (SD) codes throughout were statements wherein participants were required to choose one of these options. In order to examine the legality of the study mechanism, a pilot survey was carried out on retail consumers from the same area in which the study was conducted.

A total of 155 questionnaires were distributed to the retail consumers in Limpopo Province. Of 135 responses received, $15(9.67 \%)$ responses were not usable, and 20 (12.90\%) responses were not returned. Therefore, the study made use of the available 120 responses for the analysis. Before data were analysed, the researcher carried out data cleaning, which included coding and editing of the gathered data and analysis of data made use of MS Excel and then imported the data to Statistical Package for Social Sciences (SPSS).

\section{Ethical considerations}

The necessary ethical clearance was obtained from the Research Ethics Committee of Tshwane University of Technology with Ref \#: FCRE/ICT/2017/03/004(2). The study also ensured that participants' privacy and confidentiality were maintained, all issues raised by them were respected and taken into consideration. The Research Ethics Committee had approved the questionnaire for this research study.

\section{Data analysis and results Demographics of the participants}

Limpopo Province has a population of 5.4 million, $2.6 \%$ of the population being white, $96.67 \%$ being black Africans, $0.33 \%$ of the population is Indian or Asian, $0.27 \%$ of the population is coloured and others contribute only $0.16 \%$ of the population. The majority of the population, $86.7 \%$, resides in rural areas and $13.3 \%$ of the population lives in urban areas (Udjo 2014). The population distribution of the province has remained relatively constant according to the (Statistics South Africa 2016a) report. In Limpopo Province, the rural and urban populations are not equally distributed.

International Business Machines (IBM) SPSS 24 was used for data analysis, and to analyse the demographics of the participants. The majority of the participants, 52 (43.3\%) were males, and 68 (56.7\%) females. The majority of the participants were between the ages 26 and 35 years (42.5\%), followed by 18 and 25 years $(33.3 \%)$ and then by age group between 36 and 45 years $(17.5 \%)$. This was followed by age group between 46 and 55 (6.7\%). The majority of the participants, $40.8 \%$ hold diplomas, and $20.8 \%$ of them hold bachelor's degree, $13.3 \%$ of them are certificate holders, whilst $12.5 \%$ of the participants had matric certificates and postgraduate degrees.

The occupational positions reported indicated that $59.2 \%$ of the participants are employed full time, with $23.3 \%$ of the participants not employed, whilst $17.5 \%$ of the participants are employed as interns. Of the participants, $44.2 \%$ of them earned an income of R4000 or more, followed by $18.3 \%$ participants earning between R3000 and R3999, 16.7\% participants earned between R0 and R999 and 14.2\% of participants earned between R2000 and R2999 per month. Besides, 6.7\% of participants earned between R1000 and R1999.

\section{Online shopping usage and experience of the participants}

The majority of participants $(51.7 \%)$ indicated that they had used online shopping, compared with (48.3\%) participants who have never used online shopping before. Of the participants, $49.2 \%$ revealed that they do not use 
online shopping at all, whereas $26.7 \%$ stated that they use online shopping occasionally; $9.2 \%$ of the participants used online shopping often, whilst $8.3 \%$ used online shopping regularly and only $6.7 \%$ of the participants used online shopping frequently.

\section{The relative advantage of online shopping}

A total of $73.4 \%$ of participants indicated that online shopping makes it easy for them to conduct their shopping; only $14.2 \%$ of the participants were uncertain, whereas $12.5 \%$ disagreed with the statements. Furthermore, a total of more than $50.8 \%$ of participants indicated that online shopping gives them greater control in managing their shopping more efficiently.

\section{The compatibility of online shopping}

The majority of participants $(57.5 \%)$ indicated that they agree that using online shopping suits their work-style, only $20.8 \%$ of participants were uncertain, whilst $21.6 \%$ of participants disagreed with the statements. Whilst the majority of participants (54.2\%) indicated that online shopping is more convenient than traditional shopping and $23.3 \%$ of participants were uncertain, whilst only $22.5 \%$ of participants disagreed with the statement. Of the participants, $54.2 \%$ indicated that online shopping is compatible with the way they like to shop, only $20.8 \%$ of participants were uncertain, whilst $25 \%$ of participants disagreed with the statement.

\section{The complexity of online shopping}

The majority of the participants (67.5\%) indicated that they agree that online shopping makes it easier for them to do their shopping, only $14.2 \%$ of participants were uncertain, whilst $18.4 \%$ of participants disagreed with the statement. Whilst majority of participants (56.6\%) agreed that online shopping is simple, only $19.2 \%$ of participants indicated their uncertainty, whilst $24.2 \%$ of the participants disagreed with the statements. Furthermore, $58.3 \%$ of participants agreed that learning to use online shopping sites is easy, whilst only $15.8 \%$ of participants highlighted their uncertainty and only $25.8 \%$ of participants disagreed with the statements.

\section{The trialability of online shopping}

At least $67.5 \%$ of participants indicated that they want to try online shopping for at least a month, only $18.3 \%$ of the participants indicated that they were uncertain, other participants did not want to try online shopping. Once again, the majority of participants (65\%) indicated that they want to try online shopping to understand how it works, only $22.5 \%$ of the participants indicated that they were uncertain and only $12.5 \%$ of the participants disagreed with the statements. Of the total participants, $55 \%$ of the participants indicated that they have tried online shopping before, only 5.0\% indicated their uncertainty and only $40 \%$ of participants disagreed with the statement.

\section{The security of online shopping}

The majority of the participants (36.6\%) agreed that using online shopping is safer than walking into a retail store, only $29.2 \%$ of participants were unsure about online shopping security, whilst $34.1 \%$ of the participants disagreed with the statement. Once again $54.1 \%$ of participants agreed that retailers who offer online shopping have security measures in place to protect consumers, only $31.7 \%$ of participants were uncertain, whilst only $14.2 \%$ of the participants disagreed with the statement.

\section{The awareness of online shopping}

The majority of the participants (75.9\%) indicated that they were aware of online shopping and the services offered, only $14.2 \%$ of participants indicated their uncertainty, whilst $10 \%$ of participants disagreed with the statement. Once again $70.8 \%$ of participants indicated that they were aware of what they had to do to become online shopping consumers, whilst only 12.5 of the participants were uncertain and only $16.7 \%$ of the participants disagreed with the statements. Furthermore, majority of the participants $(72.5 \%)$ indicated that they were aware of the service offered by online shopping; only $15.8 \%$ of the participants indicated their uncertainty, whilst only $11.7 \%$ of the participants disagreed with the statements.

\section{The intention to accept and use online shopping}

The majority of the participants (79.1\%) indicated that they intend to accept and use online shopping in the future; only $9.2 \%$ of the participants were unsure whether they intend to accept and use online shopping in the future and only $11.7 \%$ of the participants indicated they had no intention to accept and use online shopping in the future.

\section{Reliability test}

The reliability test was conducted using Cronbach's alpha coefficient in order to determine the reliability of the constructs in this study. The Cronbach's alpha coefficient value for this study ranged from 0.471 to 0.960 is indicated (Table 1).

\section{Correlation analysis}

The different constructs of this research paper, namely, relative advantage, compatibility, complexity, trialability, security, awareness and intention to accept and use online shopping, were analysed using Pearson's correlation analysis. This was to check the trend and intensity of relations that exist amongst constructs. The correlation analysis results are outlined (Table 2).

\section{Regression analysis}

The study used the regression pattern to establish the extent to which relative advantage, compatibility, complexity, trialability, awareness and security influence the intention to accept and use online shopping in Limpopo Province. The regression results reflected (Table 3) indicated a significant value of 0.000 , denoting that the 
regression model may be used reliably to make recommendations to retail consumers concerning online shopping acceptance and use. The predictor variables in this study account for $77.4 \%$ of the variance on the acceptance and use of online shopping (Adjusted $R$ Square $=0.774$ ). The significant predictor of the acceptance and use of online shopping has been identified to be trialability. Compatibility, security, complexity, followed by relative advantage and awareness were found as not the significant factors on the acceptance and use of online shopping. In order for retail consumers to significantly improve their

TABLE 1: Reliability analysis using Cronbach's alpha: Item statistics.

\begin{tabular}{|c|c|c|c|c|}
\hline Construct & Indicator & Mean & Standard deviation & Alpha $(\alpha)$ \\
\hline \multirow{4}{*}{$\begin{array}{l}\text { Relative } \\
\text { advantage }\end{array}$} & REALD1 & 2.14 & 1.063 & \multirow[t]{4}{*}{0.893} \\
\hline & REALD2 & 2.56 & 1.201 & \\
\hline & REALD3 & 2.44 & 1.194 & \\
\hline & REALD4 & 1.88 & 1.139 & \\
\hline \multirow[t]{4}{*}{ Compatibility } & COMPA1 & 2.46 & 1.187 & \multirow[t]{4}{*}{0.899} \\
\hline & COMPA2 & 2.54 & 1.202 & \\
\hline & СОМРA3 & 2.60 & 1.212 & \\
\hline & COMPA4 & 2.57 & 1.193 & \\
\hline \multirow[t]{4}{*}{ Complexity } & COMPL1 & 2.33 & 1.162 & \multirow[t]{4}{*}{0.471} \\
\hline & COMPL2 & 2.57 & 1.248 & \\
\hline & COMPL3 & 2.53 & 1.250 & \\
\hline & COMPL4 & 3.78 & 1.197 & \\
\hline \multirow[t]{4}{*}{ Security } & SEC1 & 2.95 & 1.201 & \multirow[t]{4}{*}{0.780} \\
\hline & SEC2 & 2.52 & 1.004 & \\
\hline & SEC3 & 2.53 & 1.020 & \\
\hline & SEC4 & 3.36 & 1.136 & \\
\hline \multirow[t]{4}{*}{ Awareness } & AW1 & 2.09 & 1.021 & \multirow[t]{4}{*}{0.860} \\
\hline & AW2 & 2.28 & 1.077 & \\
\hline & AW3 & 2.22 & 1.030 & \\
\hline & AW4 & 2.02 & 1.115 & \\
\hline \multirow[t]{4}{*}{ Trialability } & TRI1 & 2.25 & 1.031 & \multirow[t]{4}{*}{0.809} \\
\hline & TRI2 & 2.29 & 0.991 & \\
\hline & TRI3 & 2.73 & 1.499 & \\
\hline & TRI4 & 2.09 & 1.069 & \\
\hline \multirow{4}{*}{$\begin{array}{l}\text { Online shopping } \\
\text { intention }\end{array}$} & OSI1 & 2.02 & 1.085 & \multirow[t]{4}{*}{0.960} \\
\hline & OSI2 & 2.12 & 1.070 & \\
\hline & OSI3 & 2.14 & 1.040 & \\
\hline & OSI4 & 2.16 & 1.115 & \\
\hline
\end{tabular}

REALD, Relative advantage; COMPA, Compatibility; COMPL, Complexity; SEC, Security; AW, Awareness; TRI, Trialability; OSI, Online shopping intention. acceptance and use of online shopping, retailers must prioritise the improvement of trialability of online shopping. More retail consumers will then be willing to put online shopping to the test.

\section{Conclusions and recommendations Hypothesis testing}

In this study, there are seven hypotheses that were tested. The study further adopted a linear regression analysis to assess the assumptions, regressing every unrelated construct in contrast to the intention to accept and use online shopping. The findings of the research (Table 3) show that the intention to accept and use online shopping could be predicted by trialability. The results further indicate that relative advantage, compatibility, complexity, security and awareness have a positive correlation with online shopping acceptance and use. However, these constructs cannot be used to predict the intention to accept and use online shopping.

TABLE 3: Results of regression analysis in the study.

\begin{tabular}{lcccccc}
\hline Model 1 & \multicolumn{2}{c}{$\begin{array}{c}\text { Unstandardised } \\
\text { coefficients }\end{array}$} & \multicolumn{1}{c}{$\begin{array}{c}\text { Standardised } \\
\text { coefficients: } \\
\text { Beta }\end{array}$} & $\boldsymbol{t}$ & Significance \\
\cline { 2 - 5 } & B & Std. error & & & \\
\hline Constant & -0.665 & 0.767 & - & -0.867 & 0.388 \\
Relative advantage & 0.015 & 0.084 & 0.015 & 0.184 & 0.854 \\
Compatibility & 0.115 & 0.083 & 0.119 & 1.383 & 0.169 \\
Complexity & 0.047 & 0.101 & 0.035 & 0.464 & 0.643 \\
Security & -0.094 & 0.073 & -0.078 & -1.273 & 0.206 \\
Awareness & 0.008 & 0.065 & 0.007 & 0.118 & 0.907 \\
Trialability & 0.882 & 0.078 & 0.804 & 11.323 & 0.000 \\
\hline
\end{tabular}

Note: Dependent variable: Intention acceptance and use of online shopping; R20.786; Adjusted R20.774; F Change, 69.088

Std. error, standard error.

TABLE 4: Hypothesis acceptance and rejection test remarks.

\begin{tabular}{lllll}
\hline Hypothesis & Variables & Beta & $\boldsymbol{p}$ & Remarks \\
\hline H1 & Relative advantage & 0.015 & 0.854 & Not supported \\
H2 & Compatibility & 0.119 & 0.169 & Not supported \\
H3 & Complexity & 0.035 & 0.643 & Not supported \\
H4 & Security & -0.078 & 0.206 & Not supported \\
H5 & Awareness & 0.007 & 0.907 & Not supported \\
H6 & Trialability & 0.804 & 0.000 & Supported \\
\hline
\end{tabular}

TABLE 2: Correlation analysis results in the study.

\begin{tabular}{|c|c|c|c|c|c|c|c|c|}
\hline Variable & Category & 1 & 2 & 3 & 4 & 5 & 6 & 7 \\
\hline \multirow[t]{2}{*}{ Relative advantage $=1$} & Pearson correlation & 1 & & & & & & \\
\hline & Sig. (2-tailed) & - & - & - & - & - & - & - \\
\hline \multirow[t]{2}{*}{ Compatibility = 2} & Pearson correlation & $0.797 *$ & 1 & - & - & - & - & - \\
\hline & Sig. (2-tailed) & 0.000 & - & - & - & - & - & - \\
\hline \multirow[t]{2}{*}{ Complexity = 3} & Pearson correlation & $0.764 *$ & $0.731 *$ & 1 & - & - & - & - \\
\hline & Sig. (2-tailed) & 0.000 & 0.000 & - & - & - & - & - \\
\hline \multirow[t]{2}{*}{ Security = 4} & Pearson correlation & $0.585^{*}$ & $0.652 *$ & $0.636^{*}$ & 1 & - & - & - \\
\hline & Sig. (2-tailed) & 0.000 & 0.000 & 0.000 & - & - & - & - \\
\hline \multirow[t]{2}{*}{ Awareness $=5$} & Pearson correlation & $0.487^{*}$ & $0.563 *$ & $0.508^{*}$ & $0.453 *$ & 1 & - & - \\
\hline & Sig. (2-tailed) & 0.000 & 0.000 & 0.000 & 0.000 & - & - & - \\
\hline \multirow[t]{2}{*}{ Trialability = 6} & Pearson correlation & $0.682 *$ & $0.731 *$ & $0.583 *$ & $0.573 *$ & $0.613 *$ & 1 & - \\
\hline & Sig. (2-tailed) & 0.000 & 0.000 & 0.000 & 0.000 & 0.000 & - & - \\
\hline \multirow[t]{2}{*}{ Online shopping intention $=7$} & Pearson correlation & $0.643^{*}$ & $0.697 *$ & $0.555^{*}$ & $0.494 *$ & $0.556 *$ & $0.881^{*}$ & 1 \\
\hline & Sig. (2-tailed) & 0.000 & 0.000 & 0.000 & 0.000 & 0.000 & 0.000 & - \\
\hline
\end{tabular}

Sig., significance.

*, Correlation is significant at the 0.01 level (2-tailed). 


\section{Conclusion in relation to the research problem}

In conclusion, the study sought to find answers to the following research question: Why do retail consumers in Limpopo Province not accept and use online shopping, regardless of the accessibility of online shopping infrastructure, and the effort of the retailers in marketing online shopping? Based on the findings of the sections discussed, the overall conclusions of this study may be drawn as follows: The demographic features, age, education, occupation and income levels have an influence on the acceptance and use of online shopping in Limpopo province. Trialability was found to have an important effect on the acceptance and use of online shopping. However, relative advantage, compatibility, complexity and external variables (security and awareness) were found not to be significant factors influencing the acceptance and use of online shopping in Limpopo Province. It has been found that the majority of participants have never used online shopping. Retail consumers' lack of access to infrastructure such as computers, smartphones or tablets with Internet connection to access online shopping contributes to this situation. Security and complexity of online shopping were highlighted to have influence on the intention to accept and use online shopping in Limpopo Province. Consumers perceived online shopping as being insecure and believe that retailers offering online shopping services have not put adequate safety procedures in place to protect the consumers. They also believe that it is difficult to use online shopping. Retail consumers in Limpopo Province revealed their awareness of online shopping, and the services offered.

\section{Recommendations}

The study has given an insight into what was identified as significant factors in the increase of the acceptance and use of online shopping. The following recommendations are made in order to improve the study generalisation:

- The number of participants in future research should be increased in order to include a larger capacity and increase the possibility of simplifying the conclusion.

- There should be more studies on the acceptance and use of online shopping, more especially focussing on ways in which retail consumers in rural areas can access and use it for their convenience.

- A study should be considered in which a specific population is investigated on its plans to attempt the use of online shopping. This will, in return, reveal insights which will be of assistance to retailers before they embark on online shopping awareness.

\section{Acknowledgements}

The authors would like to thank everyone who participated in the answering of the questionnaire and all who helped us with the distribution and collection of questionnaires during data collection.

\section{Competing interests}

The authors declare that they have no financial or personal relationships that may have inappropriately influenced them in writing this article.

\section{Authors' contributions}

D.D.M. conducted the research as part of Mtech degree at Tshwane University of Technology under the supervision of S.N. Mokwena and M.N. Moeti.

\section{Funding information}

This research received no specific grant from any funding agency in the public, commercial or not-for-profit sectors.

\section{Data availability}

The data that support the findings of this study are available on request from the corresponding author, D.D. The data are not publicly available as they contain information that could compromise the privacy of research participants.

\section{Disclaimer}

The views and opinions expressed in this study are those of the authors and do not necessarily reflect the official policy or position of any affiliated agency of the authors.

\section{References}

Abdullah, A., Thomas, B., Murphy, L. \& Plant, E., 2018, 'An investigation of the benefits and barriers of e-business adoption activities in Yemeni SMEs', Strategic Change 27(3), 195-208. https://doi.org/10.1002/jsc.2195

Akroush, M.N. \& Al-Debei, M.M., 2015, 'An integrated model of factors affecting consumer attitudes towards online shopping', Business Process Management Journal 21(6), 1353-1376. https://doi.org/10.1108/BPMJ-02-2015-0022

Al-Hujran, O., Al-Lozi, E.M., Al-Debei, M.M. \& Maqableh, M., 2018, 'Challenges of cloud computing adoption from the TOE framework perspective', Internationa Journal of E-Business Research (IJEBR) 14(3), 77-94. https://doi.org/10.4018/ IJEBR.2018070105

Al-Maghrabi, T., Dennis, C. Halliday, S.V. \& BinAli, A., 2011, 'Determinants of consumer continuance intention of online shopping', International Journal of Business Science and Applied Management 6(1), 41-65.

Amati, M., 2020, The impact of sales promotion, convenience, and service quality on online shopping toward consumers buying decision: Case study of Lazada, Bangkok University, Bangkok.

Ansari, D.Z.A. \& Alhazemi, D.A., 2016, 'An emperical study of the consumer awareness and acceptance of online shopping in Saudi Arabia', International Journal of Development Research 6(2), 6918-6925.

Ansell, N., 2016, Children, youth and development, Routledge, New York.

Bama, D.M.S. \& Ragaprabha, M., 2016, 'Satisfaction of online shopping - A study with special reference to Pollachi Taluk', International Journal of Multidisciplinary Research and Modern Education II(1), 2454-6119.

Beneke, J., Sousa, S.D., Mbuyu, M. \& Wickham, B., 2016, 'The effect of negative online customer reviews on brand equity and purchase intention of consumer electronics in South Africa', The International Review of Retail, Distribution and Consumer Research 26(2), 171-201. https://doi.org/10.1080/09593969.2015.1068828

Bulmer, S., Elms, J. \& Moore, S., 2018, 'Exploring the adoption of self-service checkouts and the associated social obligations of shopping practices', Journal of Retailing and Consumer Services 42, 107-116. https://doi.org/10.1016/j.jretconser.2018.01.016

Celik, H., 2016, 'Customer online shopping anxiety within the unified theory of acceptance and use technology (UTAUT) framework', Asia Pacific Journal of Marketing and Logistics 28(2), 278-307. https://doi.org/10.1108/APJML-052015-0077

Choudhury, V. \& Karahanna, E., 2008, 'The relative advantage of electronic channels: A multidimensional view', MIS Quarterly 32(1), 179-200. https://doi.org/ $10.2307 / 25148833$

Chouk, I. \& Mani, Z., 2019, 'Factors for and against resistance to smart services: Role of consumer lifestyle and ecosystem related variables', Journal of Services Marketing 33(4), 449-462. https://doi.org/10.1108/JSM-01-2018-0046. 
Contini, M., Annunziata, E., Rizzi, F. \& Frey, M., 2020, 'Exploring the influence of corporate social responsibility (CSR) domains on consumers' loyalty: An experiment in BRICS countries', Journal of Cleaner Production 247, 119158 https://doi.org/10.1016/j.jclepro.2019.119158

Deen-Swarray, M., 2016, 'Toward digital inclusion: Understanding the literacy effect on adoption and use of mobile phones and the Internet in Africa', Information Technologies \& International Development 12(2), 29-45.

Dong-Her, S., Hsiu-Sen, C., Chun-Yuan, C. \& Lin, B., 2004, 'Internet Security: Malicious E-mails Detection and Protection', Industrial Management and Data Systems, 104(7), 613-623.

Duffett, R.G., 2017, 'Influence of social media marketing communications on young consumers' attitudes', Young Consumers 18(1), 19-39. https://doi.org/10.1108/ YC-07-2016-00622

Effective Measure, 2017, E-commerce industry report 2017, Effective Measure, s.I.

Egbetokun, A., Oluwadare, A.J., Ajao, B.F. \& Jegede, O.O., 2017, 'Innovation systems research: An agenda for developing countries', Journal of Open Innovation: Technology, Market, and Complexity 3(4), 25. https://doi.org/10.1186/s40852-017-0076-x

Elbeltagi, I., Hamad, H., Moizer, J. \& Abou-Shouk, M.A., 2016, 'Levels of business to business e-commerce adoption and competitive advantage in small and mediumsized enterprises: A comparison study between Egypt and the United States', Journal of Global Information Technology Management 19(1), 6-25. https://doi. org/10.1080/1097198X.2016.1134169

El Haddad, G., Aïmeur, E. \& Hage, H., 2018, 'Understanding trust, privacy and financial fears in online payment', in 2018, 17th IEEE International conference on trust, security and privacy in computing and communications/12th IEEE Internationa conference on big data science and engineering, TrustCom/BigDataSE, Institute of Electrical and Electronics Engineers, pp. 28-36.

Fernández-Ferrín, P., Calvo-Turrientes, A., Bande, B., Artaraz-Miñón, M. \& Galán-Ladero, M.M., 2018, 'The valuation and purchase of food products that combine local, regional and traditional features: The influence of consumer ethnocentrism', Food Quality and Preference 64, 138-147. https://doi.org/10.1016/j.foodqual.2017.09.015

Janeska, M., Zdraveski, D., Taleska, S. \& Gavriloska, I., 2017, 'Electronic retailing in macedonia-case study of ohrid region', Annals-Economy Series 2, 62-69.

Jayasubramanian, P., Sivasakthi, D. \& Ananthi, P.K., 2015, 'A study on customer satisfaction towards online shopping', International Journal of Applied Research 1(8), 489-495.

Katta, R.M.R. \& Patro, C.S., 2017, 'Influence of perceived benefits on consumers'online purchase behaviour: An empirical study', International Journal of Sociotechnology and Knowledge Development (IJSKD) 9(3), 38-64. https://doi.org/10.4018/ and Knowledge
IJSKD.2017070103

Kavitha, D.R., 2015, 'A study on consumer awareness and determinants of online shopping', International Journal of Management Research and Review 5(8), 636-642.

Krishnan, S., Sentosa, I., Nurain, S., Amalia, N., Syamim, S. \& Hafizah, W.N., 2017, 'E-commerce issues on customer's awareness in Malaysia', International Journal of Finance and Accounting 6(1), 8-12.

Lau, F. \& Price, M., 2017, 'Clinical adoption framework', in Handbook of e-health evaluation: An evidence-based approach, University of Victoria, Victoria.

Laxmi, R.A. \& Sarath, K.A., 2016, 'Awareness and attitude of consumers in using internet for online purchase', International Journal of Research-Granthaalayah 4(9:SE), 26-36. https://doi.org/10.29121/granthaalayah.v4.i9(SE).2016.2507

Lin, X., Featherman, M., Brooks, S.L. \& Hajli, N., 2019, 'Exploring gender differences in online consumer purchase decision making: An online product presentation perspective', Information Systems Frontiers 21(5), 1187-1201. https://doi. org/10.1007/s10796-018-9831-1

Ling, S.C., Jusoh, M.S. \& Ishak, N.A., 2018, 'An integrative theoretical framework for understanding the role of structural capability in quality management practices on quality performance', International Journal of Asian Social Science 8(11) 974-984. https://doi.org/10.18488/journal.1.2018.811.974.984

Maggioni, I., Sands, S.J., Ferraro, C.R., Pallant, J.I., Pallant, J.L., Shedd, L. et al., 2020, 'Consumer cross-channel behaviour: Is it always planned?', International Journal of Retail \& Distribution Management 48(12), 1357-1375. https://doi.org/10.1108/ IJRDM-03-2020-0103

Malhotra, G. \& Aggarwal, R., 2019, 'Growth prospects of e-retailing in electronic goods markets', International Journal of Management \& Entrepreneurship Research 1(2), 71-88.

Malhotra, N.K. \& Dash, S., 2016, 'Marketing research: An applied orientation, Pear 'Overview of Zika infection, epidemiology, transmission and control measures', Journal of Infection and Public Health 10(2), 141-149. https://doi.org/10.1016/j. jiph.2016.05.007
Pillay, P.D., 2016, 'Consumer online buying patterns: A South African perspective', Doctoral dissertation, UKZN, Durban

Rabaan, A.A., Bazzi, A.M., Al-Ahmed, S.H., Al-Ghaith, M.H. \& Al-Tawfiq, J.A., 2017, 'Overview of Zika infection, epidemiology, transmission and control measures', Journal of Infection and Public Health 10(2), 141-149. https://doi.org/10.1016/j. jiph.2016.05.007

Rahman, M.A., Islam, M.A., Esha, B.H., Sultana, N. \& Chakravorty, S., 2018, 'Consumer buying behavior towards online shopping: An empirical study on Dhaka city, Bangladesh', Cogent Business \& Management 5(1), 1514940. https://doi.org/ Bangladesh', Cogent Business \&
10.1080/23311975.2018.1514940

Rahman, M.T., 2016, 'Customers' attitude towards online shopping: The case of Bangladesh', World 6(2), 82-91

Ramavhona, T.C. \& Mokwena, S., 2016, 'Factors influencing internet banking adoption in South African rural areas', South African Journal of Information Management 18(2), 1-8. https://doi.org/10.4102/sajim.v18i2.642

Rodrigues, L.F., Oliveira, A. \& Costa, C.J., 2016, 'Playing seriously - How gamification and social cues influence bank customers to use gamified e-business applications', Computers in Human Behavior 63, 392-407. https://doi.org/10.1016/j. computers in 2016.05 .063

Rogers, E.M., 1983, Diffusion of innovation, 3rd edn., The Free Press, New York, NY.

Rogers, E.M., 1995, Diffusion of innovation, 4th edn., The Free Press, New York, NY.

Shafiee, M.M. \& Bazargan, N.A., 2018, 'Behavioral customer loyalty in online shopping: The role of e-service quality and e-recovery', Journal of Theoretical and Applied Electronic Commerce Research 13(1), 26-38. https://doi.org/10.4067/ S0718-18762018000100103

Shanthi, D.R. \& Kannaiah, D.D., 2015, 'Consumers'perception on online shopping', Journal of Marketing and Consumer Research 13, 14-20.

Sheth, J., 2020, 'Impact of Covid-19 on consumer behavior: Will the old habits return or die?', Journal of Business Research 117, 280-283. https://doi.org/10.1016/j. jbusres.2020.05.059

Shi, S., Wang, Y., Chen, X. \& Zhang, Q., 2020, 'Conceptualization of omnichannel customer experience and its impact on shopping intention: A mixed-method approach', International Journal of Information Management 50, 325-336. https://doi.org/10.1016/j.ijinfomgt.2019.09.001

Statistics South Africa, 2016a, Community survey 2016 statistical release, Statistics South Africa, Pretoria.

Statistics South Africa, 2016b, General house gold survey, Statistics South Africa, Pretoria.

Sudha, M. \& Sheena, K., 2017, 'Impact of influencers in consumer decision process: The fashion industry', SCMS Journal of Indian Management 14(3), 14-30.

Tankovic, A.C. \& Benazic, D., 2018, 'The perception of e-servicescape and its influence on perceived e-shopping value and customer loyalty', Online Information Review 42(7), 1124-1145. https://doi.org/10.1108/OIR-12-2016-0354

Tarhini, A., Alalwan, A.A. Shammout, A.B. \& Al-Badi, A., 2019, 'An analysis of the factors affecting mobile commerce adoption in developing countries', Review of International Business and Strategy 29(3), 157-179. https://doi.org/10.1108/ International Business

Udjo, E.O., 2014, 'Estimating demographic parameters from the 2011 South Africa population census', African Population Studies 28, 564-578.

Van Droogenbroeck, E. \& Van Hove, L., 2017, 'Adoption of online grocery shopping: personal or household characteristics?', Journal of Internet Commerce 16(3), personal $255-286$.

Vaidya, A. \& Vaidya, V., 2017, 'Online shopping trends among college students', International Journal of English Language Literature in Humanities V(VIII), 92-106.

Wang, B., Abdalla, E., Atrio-Barandela, F. \& Pavon, D., 2016, 'Dark matter and dark energy interactions: Theoretical challenges, cosmological implications and observational signatures', Reports on Progress in Physics 79(9), 096901. https:// doi.org/10.1088/0034-4885/79/9/096901

Yaseen, H., Dingley, K. \& Adams, C., 2016, An empirical study of factors influencing e-commerce customers'awareness in Jordan, Institute of Electrical and Electronics Engineers, s.l.

Zendehdel, M. \& Paim, L.H., 2015, 'Investigating the perceived innovation attributes, towards online shopping in Malaysia', Asian Journal of Social Sciences and Humanities 4(2), 15-23. https://doi.org/10.1080/23311975.201 5.1078428 